\title{
Determinants of Intellectual Capital Performance in Indonesian Manufacturing Companies
}

\author{
Pandu Harirangga ${ }^{1 *}$, Rosinta Ria Panggabean ${ }^{1}$ \\ ${ }^{1}$ Accounting Department, Faculty of Economics and Communication, Bina Nusantara University, Jakarta, Indonesia \\ "Corresponding author. Email: ph_rangga@yahoo.co.id
}

\begin{abstract}
In the last few decades, the world has been undergoing rapid advancements in science and technology that influence global economic development. A change from industrial to science-based economy has also embarked. Science holds a prominent role in the utilization of intangible resources in the form of intellectual capital that should be disclosed to investors. This research is aimed at investigating whether intellectual capital performance is influenced by firm size, age, profitability, and ownership. This research was a quantitative study from secondary data and the VAICTM model. 152 manufacturing companies listed on the Indonesia Stock Exchange in the period 2014-2017 were chosen as the sample. Two analysis methods were employed, namely descriptive analysis and panel data regression analysis. Results indicated that firm age had a significant effect on intellectual capital performance, while firm profitability had a positive effect on intellectual capital performance. However, firm size and firm ownership had no significant effect on intellectual capital performance. Many of the manufacturing companies in Indonesia have yet to focus on intellectual-capital-based business. It is thus recommended that manufacturing companies in Indonesia increase their focus on intellectual capital.
\end{abstract}

Keywords: intellectual capital, Indonesia, size, age, profitability, ownership

\section{INTRODUCTION}

The world economy has undergone a change from an industrial economy that is a business model based on the utilization of real resources to a knowledge-based economy that is a business model based on the utilization of invisible resources [1]. In this new paradigm, knowledge is considered as an important aspect in the utilization of invisible resources. This has led to changes in the business strategies of many companies that have previously implemented a labor-based business strategy to one that is knowledge-based [2]. Knowledge-based business strategies require companies to disclose invisible resource information in the form of intellectual capital to investors [3]. In a knowledge-based business strategy, intellectual capital needs to be expressed as a form of investment belonging to the company because it can affect the value of a company [4].

Intellectual capital needs to be managed properly to increase the value of the company and provide a competitive advantage for the company so that company goals can be achieved [5]. Well-managed intellectual capital can create new business innovations to overcome competition in the market, as well as provide long-term sustainable advantages for companies [6].

The manufacturing sector has the potential to have human resources that can produce good intellectual capital performance; this is because manufacturing sector companies need to utilize their human resources to provide innovation and technology development for the performance and products produced for the company, even though the more service companies rely on intangible assets compared to manufacturing companies who rely more on tangible assets [7].

Intellectual capital began to be developed in Indonesia after the existence of PSAK 19 (Revised 2015) that describes intangible assets. President Joko Widodo also appealed to the importance of economic creation and innovation in supporting development in Indonesia during his administration; intellectual capital subsequently became an important foundation for companies in Indonesia to provide creations and innovations on the products marketed [8].

Firm size can affect intellectual capital performance because the larger a company, the greater the company's facilities, including access to the capital market and society in general. This encourages large companies to continue to innovate through intellectual capital performance to develop products so the company can continue to compete with other companies [9]. Companies that are considered older usually have better company performance compared to companies that are younger when considering a number of factors, such as expertise in human resources, brands, and the scale of the economy [9]. A firm's good profitability is very important for them to maintain company sustainability. A large number of corporate shareholders in a company can cause conflicts that can affect company management policies [10]. This contradiction occurs because management needs to improve the company's performance simultaneously along with their personal gain.

Research on intellectual capital performance has been widely carried out in other countries, but has been rarely done in Indonesia. Therefore, this study seeks to reveal several factors that influence the intellectual capital performance of several companies in Indonesia, particularly 
in manufacturing sector companies listed on the Indonesia Stock Exchange (IDX) in 2014-2017.

The purpose of this study is to determine whether a firm's size, firm's age, firm's profitability, and firm's corporate ownership affect intellectual capital performance. This research is expected to be beneficial, firstly, as material for consideration and source of information for management to pay more attention and develop the importance of intellectual capital performance because it can improve company performance, increase competitive advantage and increase the trust of stakeholders. Secondly, as consideration for information in making investment decisions and granting credit to companies. Third, to provide information and references to those who want to use research on the factors that influence intellectual capital performance in the manufacturing sector so that it can be used as a reference.

\section{METHODS}

\subsection{Research Design}

The type of data used in this study was secondary data, while the data source in this study were financial statement and annual report data from manufacturing companies listed on the Indonesia Stock Exchange (IDX). The financial statement data was taken from the website www.idx.co.id, while company names were obtained from the fact book data on the IDX website. Panel data was used in this study. The object of research was manufacturing companies listed on the Indonesia Stock Exchange (BEI) for four consecutive years from 2014 to 2017. The purposive sampling method was used to determine the sample in this study. The sample collection method used was the documentation method. The research sample was selected using the following criteria:

a. Manufacturing sector companies listed on the Indonesia Stock Exchange (IDX) from 2014-2017.

b. Companies that presented fully audited annual financial statements from 2014-2017.

c. The company uses the unit of Rupiah (Rp).

d. Companies that have the required data in full from 2014-2017.

\subsection{Data Analysis Method}

The data analysis method used was the descriptive data analysis technique. This technique uses multiple linear regression analysis techniques using Eviews version 9.0. Tests conducted in this study consisted of descriptive statistical, OLS regression, and hypothesis tests [17]. Here is the formula for the multiple linear regression analysis in this study:

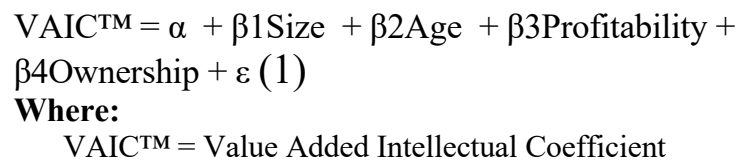

\author{
$\alpha=$ Constanta \\ $\beta 1-\beta 4=$ Coefficient of Regression \\ Size $=$ Company Size \\ Age $=$ Company Age \\ Profitability $=$ Level of profit \\ Ownership = Corporate Ownership \\ $\varepsilon=$ Error Term
}

\subsection{Operationalization of Variables}

The variables that were operationalized in this study are as follows:

\subsubsection{Dependent Variable}

In this study, the dependent variable is intellectual capital performance, which is represented by the value-added intellectual coefficient (VAIC ${ }^{\mathrm{TM}}$ ). The VAIC ${ }^{\mathrm{TM}}$ value can be calculated as follows:

a. Calculate Value Added (VA) [11]

$\mathrm{VA}=$ OUTPUT - INPUT (2)

Where:

$\mathrm{VA}=$ Value Added

OUTPUT $=$ Total Profit

INPUT $=$ Product or Service Costs (Expense)

In this model, salaries and wages are not considered as costs because these types of costs play a major and important role in value creation and are considered as capital.

b. Calculate Value Added Structural Capital (VASC)

VA is influenced by structural capital, which in this case is labeled VASC. Pulic assumes that if 1 unit of structural capital generates a greater return than other companies, it means that the company is better at utilizing its structural capital. VASC can be calculated using the following formula [11]:

$$
\begin{aligned}
& \text { VASC = VA / SC (3) } \\
& \text { Where: } \\
& \text { VASC = Value Added Structural Capital } \\
& \text { SC }=\text { Structural Capital }
\end{aligned}
$$

c. Calculate Value Added Human Capital (VAHC)

The next relationship is VA and HC which shows how much VA can be generated with funds released for labor. VAHC can be calculated with the following formula [11]:

$$
\begin{aligned}
& \text { VAHC = VA / HC (4) } \\
& \text { Where: } \\
& \text { VAHC = Value Added Human Capital }
\end{aligned}
$$

d. Calculating Relation Capital Value Added (RCVA)

The next relationship is between relation capital and value added. Relation capital is obtained by calculating the difference between VA and HC. Then the RC can be calculated as follows [11]:

$\mathrm{RC}=\mathrm{VA}-\mathrm{HC}$ (5)

\section{Where:}

$$
\mathrm{RC}=\text { Relation Capital }
$$

After the RC is calculated, the next step is to find the value of RCVA with the following formula [11]:

$\mathrm{RCVA}=\mathrm{RC} / \mathrm{VA}(6)$ 


\subsection{Descriptive Statistics}

RCVA = Relation Capital Value Added

e. Calculating Value Added Intellectual Coefficient (VAICTM)

The last ratio is to calculate the company's intellectual abilities by adding up the coefficients that have been calculated previously. The calculation results are formulated in the VAIC TM indicator [11].

$\mathrm{VAIC}^{\mathrm{TM}}=\mathrm{VACA}+\mathrm{VAHC}+\operatorname{RCVA}(7)$

\subsubsection{Independent Variables}

Four independent variables used in this study, namely firm size, firm age, profitability, and corporate ownership. The following is the description of the operationalization of each independent variable in this study:

a. Company Size

Logarithm of total assets for company $i$ in year $t$ [9]

Firm Size $=$ LogTotal Asset (8)

b. Firm Age

The logarithm of company age $i$ in year $t$, measured by the number of years for the company since starting business until each year of the research period [9].

Firm Age $=$ logAge (9)

c. Firm Profitability

The net income before tax of each company $i$ is divided by total assets in year $\mathrm{t}$ [9].

Firm Profitability $=$ Earnings Before Tax $/$ Total Asset (10)

d. Firm Corporate Ownership

A firm's corporate ownership is the share ownership by other companies [10].

Firm Corporate Ownership $=$ Percentage of corporate share ownership of company ownership. (11)

\section{RESULTS AND DISCUSSION}

The companies that were the objects of this research were manufacturing sector companies listed on the Indonesia Stock Exchange in the period 2014 to 2017. Based on the predetermined criteria, the results of sample selection are summarized as follows:

Table 1 Sample Selection

\begin{tabular}{|lll|}
\hline 1 & $\begin{array}{l}\text { Manufacturing sector companies listed on the } \\
\text { Indonesia Stock Exchange (IDX) from 2014- } \\
2017\end{array}$ & 152 \\
\hline 2 & $\begin{array}{l}\text { Companies that did not present complete } \\
\text { audited annual financial statements from } \\
2014-2017\end{array}$ & $(13)$ \\
\hline 3 & $\begin{array}{l}\text { Companies that do not use Indonesian Rupiah } \\
\text { (Rp) }\end{array}$ & $(29)$ \\
\hline 4 & $\begin{array}{l}\text { Companies that did not have the required } \\
\text { financial data in full }\end{array}$ & $(1)$ \\
\hline Number of Company Samples & $\mathbf{1 0 9}$ \\
\hline & Research Period & $\mathbf{4 Y e a r}$ \\
\hline Number of Data (109 companies x 4 years) & $\mathbf{4 3 6}$ \\
\hline Source: Data processed, 2019
\end{tabular}

The following are the results of the descriptive statistical analysis that was carried out using the Eviews software:

Table 2 Descriptive Statistics

\begin{tabular}{|cccccc|}
\hline & $\mathbf{N}$ & Mean & Maximum & Minimum & Std. Dev. \\
\hline VAIC $^{\text {TM }}$ & 436 & 5.55 & 30.61 & $(165.75)$ & 9.56 \\
\hline Size & 436 & 6.25 & 8.47 & 4.59 & 0.69 \\
\hline Age & 436 & 1.52 & 1.94 & 0.70 & 0.18 \\
\hline Profitability & 436 & 0.07 & 0.73 & $(0.55)$ & 0.13 \\
\hline Ownership & 436 & 0.64 & 1.00 & 0.00 & 0.26 \\
\hline
\end{tabular}

Source: data processed with Eviews version 9, 2019

\subsection{Classic Assumption Test}

Based on normality test results, manufacturing sector companies in Indonesia have a jarque value of 736103.7, if the jarque value $>$ or greater than 2 , then the data is not normally distributed. In addition, the probability value is 0.000000 where $<0.05$, so a small probability value tends to lead to the rejection of the null hypothesis of normal distribution, which means that the data are not normally distributed.

An outlier test was then performed to free the research data from outlier values or extreme values. Outlier testing is performed using a histogram chart, which is provided by the Eviews 9 application. Furthermore, the picture of the histogram graph will be examined, ie a value very far from the correlation number is called an extreme value or outlier value. This number will then be erased by eliminating the company from the initial company sample.

Based on the results of outlier testing, two Indonesian manufacturing companies were found and were eliminated by the JPRS and IKAI stock codes. So the sample of manufacturing companies in Indonesia after the outlier test amounted to 107 companies.

The following are the results of the multicollinearity test:

Table 3 Multicollinearity Test

\begin{tabular}{|llllll|}
\hline & VAIC $^{\text {TM }}$ & Size & Age & Profitability & Ownership \\
\hline VAIC & 1.0000 & 0.0937 & 0.0098 & 0.2514 & 0.0058 \\
\hline Size & 0.0937 & 1.0000 & 0.1963 & 0.2020 & $(0.0196)$ \\
\hline Age & 0.0098 & 0.1963 & 1.0000 & 0.3475 & 0.1010 \\
\hline Profitability & 0.2514 & 0.2020 & 0.3475 & 1.0000 & 0.0563 \\
\hline Ownership & 0.0058 & $(0.0196)$ & 0.1010 & 0.0563 & 1.0000 \\
\hline
\end{tabular}

Multicollinearity test results showed no correlation values of above 0.90 , so there was no multicollinearity in the model [12].

This study implemented the Glejser test to detect the presence of heteroscedasticity. Based on the results of heteroscedasticity testing on manufacturing sector companies in Indonesia, the F-Statistic value was 0.978932 and the probability was 0.4187 greater than $\alpha=5 \%$. This indicates that the data of this study do not contain heteroscedasticity.

The Durbin-Watson test method was used in this study to determine whether autocorrelation occurred in the observation data. Based on the results of the Durbin-Watson 
value of 1.866900 , it can be proven that there was no correlation between variables.

\subsection{Hypothesis Test}

From the determination coefficient test results, it is known that the adjusted R2 value obtained is 0.193611 or $19.36 \%$. So it can be concluded that as much as $19.36 \%$ of the dependent variable of intellectual capital performance can be explained in the variance of the independent variables, namely firm size, firm age, firm profitability, and firm corporate ownership. Meanwhile, the value of $80.64 \%$ $(100 \%-19.36 \%)$ can be explained by other factors not included in the regression model.

The F statistical test shows the significance value is 0.000 smaller than 0.05 . In accordance with the decision-making criteria, if a significant value is less than 0.05 it means that firm size, firm age, firm profitability, and firm corporate ownership affect intellectual capital performance.

The following are the results of the hypothesis test:

Table 4 Hypothesis Test

\begin{tabular}{|cc|}
\hline Variable & Prob. \\
\hline Y & 0.0009 \\
\hline X1 & 0.5169 \\
\hline X2 & 0.0071 \\
\hline X3 & 0.0000 \\
\hline X4 & 0.9156 \\
\hline
\end{tabular}

The statistical test $t$ shows that the independent variables of firm age and firm profitability have a significance value of 0.0071 and 0.0000 , respectively, which is less than a significant value of 0.05 . Therefore, Ho is rejected, meaning that the firm age and firm profitability variables have an influence on intellectual capital performance. Meanwhile, the independent variable of firm size and firm corporate ownership have a significant value of 0.5169 and 0.9156 , respectively, where the value is more than a significant value of 0.05 , meaning that $\mathrm{Ho}$ is accepted. It can be concluded that firm size and firm corporate ownership have no effect on intellectual capital performance.

Analysis of the multiple linear regression test produces the following equation:

VAICTM $=8.469701+0.206008$ Size $+(3.343609)$ Age

+18.56896 Profitability +0.086691 Ownership $+\varepsilon$

\subsection{Effect of Firm Size on Intellectual Capital Performance}

The firm size variable produces a significance value of 0.5169 ; it is greater than the significance level of 0.05 , thus firm size does not have a significant effect on intellectual capital performance. The results of this test are not in accordance with research by [9] which states that firm size has a significant positive effect on intellectual capital performance.
The reason why firm size does not have a positive influence on intellectual capital performance is because it does not become a reference in being able to utilize the company's human resources effectively. Large companies certainly have greater human resources, but these resources do not necessarily show a balanced performance with the size of a company. Intellectual capital performance is more influenced by the resources themselves, namely their knowledge capital compared to the size of a company where they work. Referring to stakeholder theory, the greater a company, the greater the creation of corporate value, company management must be able to manage all the company's resources to the maximum so that it can increase the value of the company [13], but in this study it becomes a challenge for management where the greater the resources within a company will also make it more difficult to manage effectively. This can be proven by looking at examples at PT. Astra International Tbk. In 2017, the company had total assets of Rp. 295,646,000,000,000 as a firm size indicator but only had a VAIC TM value of 5.18. This is relatively low compared to the maximum value of VAIC TM owned by PT. Delta Jakarta Tbk. in 2014 that amounted to 30.61 with a total asset value of only Rp. 997,443,000,000.

\subsection{Effect of Firm Age on Intellectual Capital Performance}

The firm age variable produces a significance value of 0.0071 , a value lower than the significance level of 0.05 . Meanwhile, the value of the firm age variable regression coefficient on intellectual capital performance is $-3,343609$. Therefore, it can be concluded that firm age has a significant negative effect on intellectual capital performance. These results are not consistent with research conducted by [9] which states that firm age has a positive influence on intellectual capital performance.

Older companies will usually not focus their business processes on intellectual capital because the company has to be able to ensure its sustainability in conducting business [14]. If an older company does not have a focus on intellectual capital, younger companies will pay attention to intellectual capital to improve the company's performance in its business processes. This can be proven by looking at PT. Star Petrochem Tbk. which has a VAIC TM value of 18.95 , which is quite large, but the company was only 6 years old from 2008 to 2014 .

\subsection{Effect of Firm Profitability on Intellectual Capital Performance}

The firm profitability variable produces a significance value of 0.0000 , which is lower than the significance level of 0.05 . Meanwhile, the value of the regression coefficient of firm profitability variables on intellectual capital performance is 18.56896. It can be concluded that firm profitability has a significant positive effect on intellectual capital performance. These results are consistent with research conducted by [9] which states that firm profitability has a positive influence on intellectual capital performance. 
Manufacturing companies are more likely to use physical capital so that the resources owned by the company can be affected by profitability. This study also shows that the capital used is the value of assets that contribute to the company's ability to generate revenue. So if the capital used by a company is a relatively large amount, it will also result in the company's total assets to be relatively large. The company's revenue will also increase. This can increase the return on a number of assets owned by the company. The company has succeeded in increasing the productivity of assets in it if the total assets are part of intellectual capital, which are intangible assets that have an important role in advancing the performance of the company [15].

\subsection{Influence of Firm Corporate Ownership on Intellectual Capital Performance}

The firm corporate ownership variable produces a significance value of 0.9156 more than 0.05 , so firm corporate ownership has no significant effect on intellectual capital performance. The results of this test are not in accordance with the research made by [10].

Firm corporate ownership is not a reference for it to be able to utilize the company's human resources effectively. Companies that have a share of capital stock on behalf of a corporation certainly have better management when compared to the distribution of share capital owned by the general public; this is because a corporation can oversee the company's management process compared to the general public where each individual does not have a large share of capital. However, when referring to agency theory, the principal (Owner) cannot observe all activities and decisions taken by the agent (Manager), so that there is a threat that the agent will take the opportunity to prioritize his personal interests compared to the interests of the principal [16]. This proves that intellectual capital performance is not influenced by shareholders but is influenced by the focus of managers in managing the company to focus more on intellectual capital performance or other matters.

\section{CONCLUSION}

This study examines the effect of firm size, firm age, firm profitability, and firm corporate ownership on intellectual capital performance in manufacturing sector companies listed on the Indonesia Stock Exchange in 2014-2017. Based on the results of testing and discussion, conclusions can be obtained from each variable studied.

The firm size variable does not significantly influence intellectual capital performance. This result proves that many large companies in the manufacturing sector in Indonesia do not have a focus on intellectual capital performance in running their business processes. Meanwhile the firm age variable has a significant negative effect on intellectual capital performance. These results prove that the intellectual capital performance of older manufacturing companies in Indonesia tend to decrease compared to younger companies which tend to increase.
The firm profitability variable has a significant positive effect on intellectual capital performance. These results prove that the level of corporate profits is very influential on intellectual capital performance because corporate income is closely related to human resources. The firm corporate ownership variable does not significantly influence intellectual capital performance. These results prove that corporate ownership of shares does not guarantee that company management will have a focus on intellectual capital performance.

The results of the research has a number research limitations, such as the sample population of manufacturing sector companies during the research period of 2014 to 2017 included a wide or extreme range of data. This caused the distribution of data to become abnormal to meet classical assumptions as a condition for testing hypotheses and requires a solution to be able to meet these assumptions. Furthermore, this research is limited to one industrial sector and one country only, namely the manufacturing sector listed on the Indonesia Stock Exchange (IDX).

For companies, it is recommended that they consider intellectual capital performance in running their business processes so that the quality of company resources can increase the value of the company. For investors, it is recommended that they consider the intellectual capital performance of a company as one of the factors in investing. For future researchers, it is recommended that different sample variations and independent variables are used or added from this research so that research on intellectual capital performance can continue to be developed in the future.

\section{REFERENCES}

[1] V. Dženopoljac and S. Muhammed. Assessing the intellectual and knowledge based assets of organizations: Case of global oil and gas operations firms. AMCIS 2017 - 23rd America's Conference on Information Systems: A Tradition of Innovation, Boston, 2017, pp. 1 - 10. Available: http://aisel.aisnet.org/amcis2017/StrategicIT/Presentatio $\mathrm{ns} / 7 /$

[2] B. Solikhah and Subowo. (2016). An empirical study of the driver factors of the intellectual capital disclosure. Review of Integrative Business \& Economics Research. Vol. 5, Issue 1. pp. 229-240. Available:

http://buscompress.com/uploads/3/4/9/8/34980536/riber _h15-127_229-240_.pdf

[3] D. Sunitha, I.G.N. Budiasih, and I.D.N. Badera. (2017). Pengaruh pengungkapan enterprise risk management dan pengungkapan intellectual capital terhadap nilai perusahaan. Jurnal Akuntansi dan Keuangan Indonesia. Vol 14, No 1. pp 20-45. Available: http://jaki.ui.ac.id/index.php/home/article/view/515/515 
https://www.inderscience.com/info/inarticle.php?artid= 2891

[12] I. Ghozali. (2013). Aplikasi Analisis Multivariate dengan Program IBM SPSS 21 Update PLS Regresi. Semarang: Badan Penerbit Universitas Diponegoro.

[13] D.C.N.A. Sudibya and M.I.M.D. Restuti. (June, 2014). Pengaruh modal intelektual terhadap nilai perusahaan dengan kinerja keuangan sebagai variabel intervening. BENEFIT Jurnal Manajemen dan Bisnis. Vol 18, No 1, pp. 14-29. Available: http://journals.ums.ac.id/index.php/benefit/article/view/ $1390 / 944$

[14] L. Nafisah and W. Meiranto. (2017). Pengaruh karakteristik perusahaan terhadap pengungkapan modal intelektual dalam prospektus IPO. Diponegoro Journal of Accounting. Vol 6, No 3, pp. 1-11. Available: https://ejournal3.undip.ac.id/index.php/accounting/articl e/view/19279/18298

[15] M. Kartina. (2013). Pengaruh intellectual capital pada profitabilitas perusahaan perbankan yang terdaftar di Bursa Efek Indonesia pada tahun 2007-2011.

Business Accounting Review. Vol 1, No 2, pp. 14-25. Available:

http://publication.petra.ac.id/index.php/akuntansibisnis/article/view/491

[16] R.G. Schroeder, M.W. Clark, and J.M. Cathey. (2013). Financial Accounting Theory and Analysis: Text and Cases (11th ed). New York: John Wiley.

[17] Nuryanto \& Pambuko, Z. B. (2018). Eviews untuk Analisis Ekonometrika Dasar: Aplikasi dan Interpretasi. Magelang: Unimma Press.

[9] M. El-Bannany. (June, 2015), Explanatory study about the intellectual capital performance of banks in Egypt. International Journal of Learning and Intellectual Capital. Vol 12, Issue 3, pp. 270-286. Available: https://www.inderscienceonline.com/doi/abs/10.1504/IJ LIC.2015.070167

[10] F. Shahveisi, F. Khairollahi, and M. Alipour. (2017). Does ownership structure matter for corporate intellectual capital performance? An empirical test in the Iranian context. Eurasian Business Review. Vol 7, Issue 1, pp. 67-91. Available: https://link.springer.com/article/10.1007/s40821-0160050-8

[11] A. Pulic. (2000). VAIC ${ }^{\text {TM }}$ - an accounting tool for IC management. International Journal of Technology Management. Vol 20, No 5/6/7/8, pp. 702-714.

Available: 